\title{
Assessing the change of groundwater quality compared with land-use change and precipitation rate (Zrebar Lake's Basin)
}

\author{
Azad Sadeghi $^{1}$ D $\cdot$ Saman Galalizadeh ${ }^{2} \cdot$ Gholamreza Zehtabian $^{1} \cdot$ Hassan Khosravi $^{1}$
}

Received: 14 June 2021 / Accepted: 27 September 2021 / Published online: 3 October 2021

(c) The Author(s) 2021

\begin{abstract}
Population, salinity, and increasing water consumption have caused high pressure on groundwater resources in Iran. The study reported here investigates the change of groundwater quality in Zrebar lake basin and the relationship between it with land-use change and precipitation rate from 1992 to 2018. To achieve the intended goal, chemical parameters of water from wells around the lake, bicarbonate $\left(\mathrm{HCO}^{3-}\right)$, sulfate $\left(\mathrm{SO}_{4}\right)$, sodium absorption ratio (SAR), and electrical conductivity (EC) were analyzed. Then, four methods including interpolation in the ArcGIS environment, Wilcox and Schoeller Diagram in Aq.QA software and Ground Water Quality Index (GWQI) were used to indicate the trend of water quality from 1992 to 2018. To detect land-use changes from 1992 to 2018, three Landsat satellite images covering the study area were used to identify land uses and their changes during the period that shows a significant area of forests that has been replaced by agricultural use, the dominant cover in 2018, while the area of forest has declined sharply. In this study, the precipitation patterns over the past years were showed to assess the relationship between rainy and low rainfall years with water quality. The results showed that forest area in 1992, 2003 and 2018 was 70.6, 62.5 and 50.2 hectares, respectively, which shows a significant reduction, $22 \%$, during this study period. On the other hand, the area of farmlands and human-made constructions has increased by $20 \%$ and $200 \%$, respectively. This study additionally revealed that although there was a decreasing trend in the rate of rainfall and the agricultural lands have increased, the quality of water was still suitable for drinking and agriculture consumptions. Changes in groundwater quality were not justifiable by rainfall rate and land-use change because there was no significant relationship between them with all the groundwater quality parameters.
\end{abstract}

Keywords Groundwater quality $\cdot$ GWQI index $\cdot$ Wilcox diagram $\cdot$ Schoeller diagram $\cdot$ EC $\cdot$ SAR

\section{Introduction}

More than $40 \%$ of the water used for worldwide irrigation systems is deducted from groundwater resources (Siebert et al, 2010; WWAP 2009) and represents a substantial amount of freshwaters from the globe (Nistor, 2019). Over the past decades, the natural, semi-natural, and human-made areas would be negatively affected under improper land-use management (Nister and Mindrescu, 2019). Groundwater is the primary source of potable water supply for roughly

Hassan Khosravi

hakhosravi@ut.ac.ir

1 Department of Arid and Mountainous Reclamation Region, Faculty of Natural Resources, University of Tehran, Tehran, Iran

2 Department of Environment, University of Tehran, Tehran, Iran half of the world's population (Riedel, 2018) that has also been effected by land-use change. It means that land-use change as an important stressor impacts both groundwater quantity and quality (Yidana et al, 2010; Rajaei et al 2021). Land-use/land-cover changes such as deforestation, agricultural areas expansion, urbanization and other human activities directly impact water resources condition primarily through modifications to watershed hydrology processes, including soil moisture, runoff, infiltration of surface, and evapotranspiration (Labat et al., 2004; Sadeghi et al., 2018; Bounoua et al., 2018). For example, the increase in global temperatures due to human-made emissions of greenhouse gases, in particular, carbon dioxide (CO2), which has not only raised the ambient temperature but has also lowered the $\mathrm{pH}$ of water-bodies and changed precipitation intensities all over the world (Solomon et al, 2009; Adham et al, 2011; Hasan S.S., 2020). In some cases, the dramatic increase in groundwater is caused by overusing fertilizers or it is due to 
converting forest to farmland and consequently increasing in the use of chemical fertilizers (Rajaei et al, 2021). Some studies show that climate and land-use change bring about groundwater quality changes by the rise in pollutants and a decrease in groundwater level. (Prasad et al, 2008; PeñaHaro et al, 2010; Velazquez et al, 2015).

The ability to spatial analysis of groundwater quality changes is critically important in the decision-making processes for environmental managers. Several studies have been carried out on surface water and groundwater to understand water resources and their management better (Malakootian and Karami, 2004; Tayfur et al 2008; Houben et al 2009; Elci and Platt 2010; Ketata et al 2011; Mohammadi et al, 2011; Vousoughi \& Dinpashosh, 2013;), the process of temporal and spatial land-use changes using remote sensing and satellite imagery techniques (Karimi et al, 2018, Hyandye and Martz 2017; Du et al.; 2017; Kourosh Niya et al., 2019), and the relationship between land-use/landcover changes and groundwater quality (Singh et al 2010; He, et al 2020; Li et al. 2019a; Rajei et al. 2021; Henri et al 2021). Houben et al. (2009) examined the groundwater quality of the Kabul watershed in Afghanistan during 2001-2005. They found out that the groundwater hardness and salinity of the groundwater in this region increased due to the prolonged droughts. Ktata et al. (2011) also assessed the trend of changes in some groundwater hydrochemical variables of Gabès groundwater in Tunisia in the statistical period 1995-2003. They concluded that salinity and other chemical variables in the direction of groundwater flow had decreased over time. Elci and Platt (2010) evaluated the trend of changes in water quality of Nife groundwater in Turkey. They indicated that the concentration of chloride in the rainy seasons had decreased compared to the dry seasons. Furthermore, temperature and nitrate had increased, but phosphate and total hardness showed the opposite trend. In addition, the studies, which have been performed in Iran, showed a decrease in the quality of groundwater in Iran plains. The results of the reviews on the trend of the qualitative changes of groundwater in Bam and Baravat in 1998-2004 suggested a decrease in quality of the underground water (Malakootian and Karami, 2004). The results of investigating the spatiotemporal variations of groundwater quality in Qazvin plain in 2003-2007 revealed that the quality of the groundwater had decreased in wet seasons, indicating the rainfall effect on the groundwater quality (Mohammadi et al, 2011). Assessing the trend of groundwater quality changes in Ardabil plain between 1995 and 2008 presented a drop in groundwater quality (Vousoughi \& Dinpashosh, 2013). The results of the study of Singh et al (2010) indicated natural and artificial recharge led to increasing the quantity of groundwater due to change in land-use and land-cover pattern (increased area of fallow land). However, fertilizers deteriorated the quality of groundwater. He et al
(2020) investigated the relationship between groundwater quality and land-use change for Xi' an City from 2005 to 2015. The results of this study revealed that the forest has positive effects on the groundwater quality, while land used such as industrial land, urban land, and farmland, negatively impacted on groundwater quality. Rajaei et al (2021) considered nutrient reduction in a watershed located in north of Iran aiming to inform future land-use planning. Their results show that deforestation and agricultural land development have led to an increase in groundwater nitrate concentrations over the past decades, and if this trend continues, groundwater quality will deteriorate.

A few studies have been conducted on land use and water quality changes in the study area (Yusefi et al. 2011; Sahrifina et al. 2013; Imani et al. 2015 Imani et al. 2016a, b) In one of these studies conducted by Imani et al. (2015), the SWOT model was used to simulate the impact of different land use on water quality with a focus on spatial and temporal assessment of nitrate and phosphate pollution loads. In this study, the amount of nitrate and phosphorus discharge to Zrebar Lake was calculated for both dry and irrigated farming. Imani et al. in another study analyzed the impacts of the various management practices (BPMs) in critical areas to reduce water pollution with the lowest implementing costs. They developed various strategies that were prioritized through the TOPSIS multi-criteria decision method. Sharifinia et al (2013) assessed the water quality of Zrebar Lake using physico-chemical parameters and NSFWQI indicator. In this study, quality parameters including nitrite, nitrate, orthophosphate, $\mathrm{NH} 4+, \mathrm{NH} 3$, iron, salinity, electron conductivity (EC) and $\mathrm{pH}$ were measured. Most of these studies have focused on the quality and quantity of Zrebar Lake, and the quality of groundwater resources in the watershed and their relationship with land-use change have not been assessed.

The objective of this study was to investigate the relationship between land-use patterns precipitation and groundwater quality for 4 parameters including bicarbonate (HCO3-), sulfate (SO42-), sodium absorption ratio (SAR), and electrical conductivity (EC). In this study, land-use changes in Zrebar Lake watershed during three time periods, 1992, 2003, and 2018, were detected using remote sensing and satellite imagery. Then to investigate the change of groundwater quality parameters, four methods including interpolation in the ArcGIS environment, Wilcox and Schoeller Diagram in Aq.QA software and Ground Water Quality Index were used. The present research examines different methods for analyzing groundwater quality and selects the best one which presents the more accurate results. 


\section{Materials and methods}

\section{Case study region}

Lake Zrebar is aquatic habitat located at the foot of the Zagros Mountains in north-western Iran, $5 \mathrm{~km}$ from the city of Marivan (Fig. 1). It has been designated as a Ramsar Site, one of the 25th Iranian wetlands of international importance, in early 2019. i). Zrebar, a freshwater ecosystem supplied mainly by springs from the lake floor, provides a suitable habitat for a different range of birds and other animals, and 29 plant species, 74 birds, nine fish, two mammals, three reptiles, and three amphibians have been identified in this aquatic ecosystem (Ramsar Convention, 2019). The case study is the lake basin, an area of $3229.5 \mathrm{~km}^{2}$. The highest precipitation rate is in late winter and early spring, and the lowest amount is in summer. According to information of the 24-years derived from synoptic stations of Marivan, average rainfall in this region (1989-2018) has been $940.2 \mathrm{~mm}$ per year, with the highest and lowest rate in the late winter and the summer, respectively (Fig. 2). The change in precipitation shows that the amount of rainfall was decreased from 1992 to 2018, but it was the lowest between 1994 and 1996, 1998 to 2002 and 2008, which is a sign of drought in these years. The average annual temperature for the studied period is $13.7^{\circ} \mathrm{C}$.

\section{Methodology}

The present investigation aims to assess and map groundwater quality changes from 1992 to 2018 by several methods

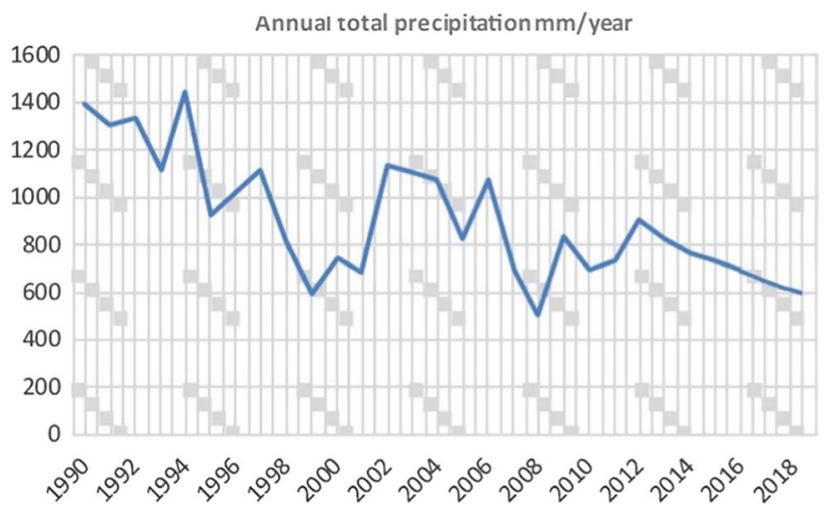

Fig. 2 The trend of precipitation in the Zrebar Lake basin (Iran Meteorological Organization, 2019)

that present the trend of groundwater quality based on time and spatial analysis. Since land use is one of the main factors affecting water quality, land-use change for the given period was also detected to recognize the areas in which land-use change has caused groundwater quality change.

\section{Land-use change detection}

To detect land-use changes from 1992 to 2018, three Landsat satellite images covering the study area were obtained from the American Geological Survey (U.S.G, 2018). Table 1 shows the characteristics of the data source. The data were analyzed in terms of radiometric errors such as stroke, the hexadecimal classes' error, and double pixels. To classify land use, visual interpretation of images was applied. Using ENVI 5.3 software, the bands 2, 3, and 4 of Landsat images
Fig. 1 The map of the location of the study area in Kurdistan province, Iran

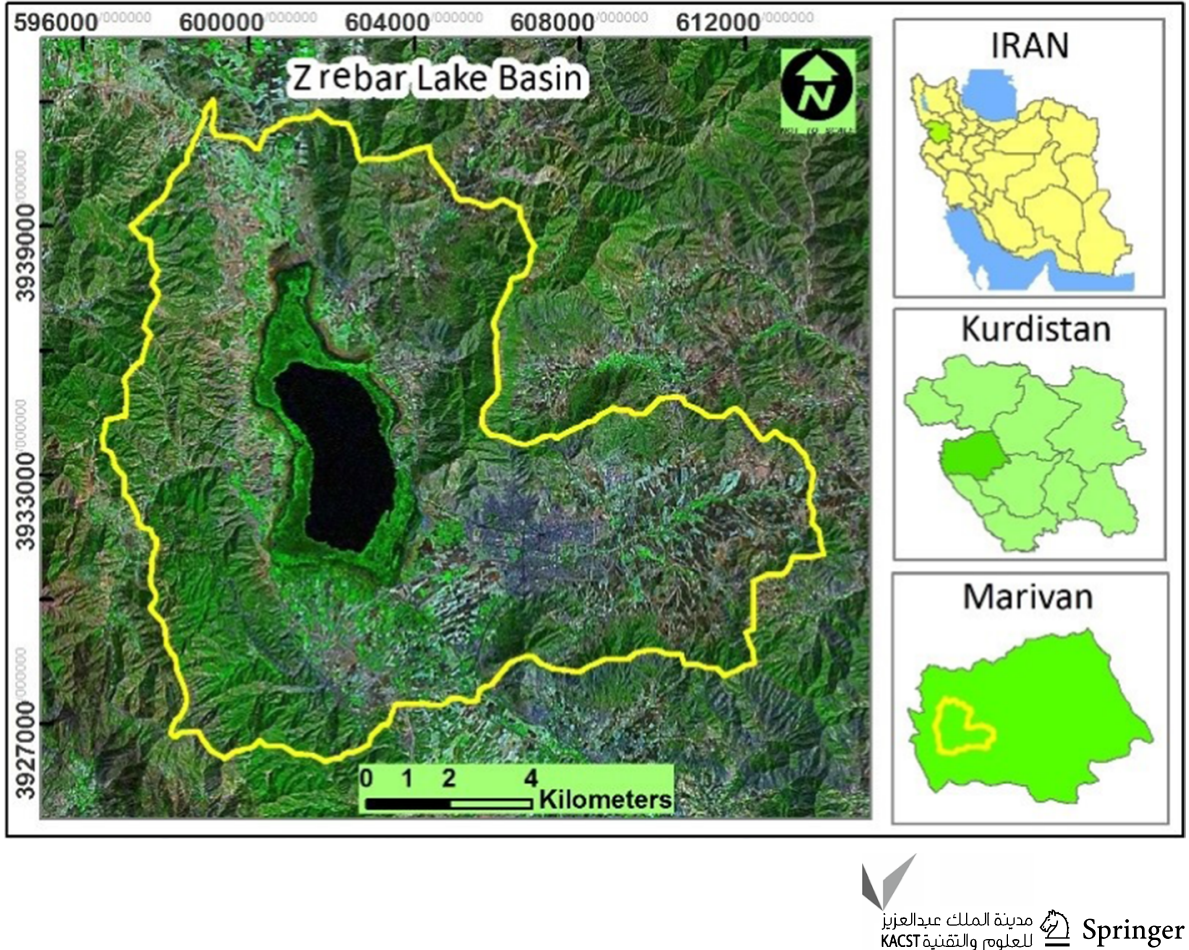


Table 1 Data source to detect land-use changes in Zrebar Lake basin

\begin{tabular}{llllll}
\hline Satellite & Sensor & Datum & Acquisition date & Path & Row \\
\hline Landsat 4 & TM & WGS84 & $20 / 06 / 1990$ & 168 & 35 \\
Landsat 4 & TM & WGS84 & $20 / 06 / 2003$ & 168 & 35 \\
Landsat 7 & ETM & WGS84 & $19 / 06 / 2018$ & 168 & 35 \\
\hline
\end{tabular}

were processed, and different classes of land use/land-cover were detected. Land use was categorized into other classes, and the accuracy of the classification of land-use maps was investigated using Google Earth images and control points. Then, Kappa coefficient was calculated to evaluate classification accuracy, which was $0 / 83$. As it is above 0.75 , it indicates high classification accuracy.

\section{Detecting water quality change}

In this study, the chemical analysis of 11 wells located in the Zrebar basin was used to assess groundwater quality change between 1992 and 2018. The measured parameters include acidity $(\mathrm{pH})$, electrical conductivity (EC), total dissolved solids (TDS), sodium adsorption ratio (SAR), some anions such as bicarbonates $\left(\mathrm{HCO}^{3-}\right)$, chloride (CL), sulfate $\left(\mathrm{SO}_{4}{ }^{2-}\right)$, as well as cations such as potassium $\left(\mathrm{K}^{+}\right)$, magnesium $\left(\mathrm{Mg}^{2+}\right)$, calcium $\left(\mathrm{Ca}^{2+}\right)$ and sodium $\left(\mathrm{Na}^{+}\right)$. To achieve this aim, the study uses different methods of analyzing the groundwater quality changes, interpolation methods for mapping the changes, Wilcox and Schoeller Diagrams for quality assessment in agriculture, and GWQI index for quality assessment of potable water.

\section{Determining the most suitable interpolation method}

One existing operational methodology for the spatial investigation of the water quality change is an interpolation, which can be conducted differently. Thus, cross-validation was used to compare the functions of interpolation methods and choose the best-fit interpolation model. The accuracy of interpolation is verified by this statistical analysis method. The original dataset can be classified into the train set and the validation set by the cross-validation method. The validation set is used to test the model obtained from the training set, which is the indicators to evaluate the model's accuracy.
Table 2 The most suitable interpolation method for groundwater quality parameters in the given period

\begin{tabular}{llllll}
\hline Period & \multicolumn{2}{l}{ Parameters } & & \\
\cline { 2 - 6 } & EC & RAR & NA & $\mathrm{HCO}^{3-}$ & $\mathrm{SO}_{4}{ }^{2-}$ \\
\hline 1992 & RBF & RBF & Kriging (Circular) & Kriging (Circular) & Kriging (exponential) \\
2003 & $\begin{array}{c}\text { Kriging } \\
\text { (Circu- }\end{array}$ & Kriging (spherical) & Kriging (exponential) & Kriging (Circular) & IDW \\
& $\begin{array}{lllll}\text { lar) } \\
2018\end{array}$ & & & & \\
\hline
\end{tabular}

Table 3 Standards of quality for drinking water, according to Schuler $\left(\mathrm{mgL}^{\cdot 1}\right)$

Table 4 Operating weight, relative weight, and the proposed measure concentrations for each parameter of groundwater quality

\begin{tabular}{llllll}
\hline Quality & $\mathrm{TH}$ & $\mathrm{TDS}$ & $\mathrm{SO}_{4}{ }^{2-}$ & $\mathrm{Cl}-$ & $\mathrm{Na}+$ \\
\hline good & $<250$ & $<500$ & $<145$ & $<175$ & $<115$ \\
acceptable & $250-500$ & $500-1000$ & $145-280$ & $175-350$ & $115-230$ \\
medium & $500-1000$ & $1000-2000$ & $280-580$ & $350-700$ & $230-460$ \\
poor & $1000-2000$ & $2000-4000$ & $580-1150$ & $700-1400$ & $460-920$ \\
very poor & $2000-4000$ & $4000-8000$ & $1150-2240$ & $1400-2800$ & $920-1840$ \\
non-drinking & $>4000$ & $>8000$ & $>2240$ & $>2800$ & $>1840$ \\
\hline
\end{tabular}

\begin{tabular}{lllllllllll}
\hline & $\mathrm{pH}$ & $\mathrm{TDS}$ & $\mathrm{EC}$ & $\mathrm{TH}$ & $\mathrm{Cl}^{-}$ & $\mathrm{HCO}^{3-}$ & $\mathrm{SO}_{4}^{2-}$ & $\mathrm{Mg}^{2+}$ & $\mathrm{Ca}^{2+}$ & $\mathrm{Na}^{+}$ \\
\hline$*_{\mathrm{Csi}}$ & 7.5 & 500 & 1500 & 300 & 250 & 45 & 250 & 30 & 75 & 200 \\
$\mathrm{Wi}$ & 2 & 5 & 5 & 3 & 5 & 5 & 4 & 2 & 3 & 4 \\
$\mathrm{Wr}$ & 0.05 & 0.13 & 0.13 & 0.08 & 0.13 & 0.13 & 0.11 & 0.05 & 0.08 & 0.11 \\
\hline
\end{tabular}

${ }^{*}$ Csi. The benchmark concentration for each ion According to the World Health Organization and (Indian standard, drinking water specification) and (IS 10500)

Wi: Operating weight

Wr: relative values of each parameter in GWQI index 
Table 5 Classification of groundwater quality for drinking based on GWQI

\begin{tabular}{llllll}
\hline $\begin{array}{l}\text { Groundwa- } \\
\text { ter quality } \\
\text { based on }\end{array}$ & Excellent & Good & Bad & Very Bad & $\begin{array}{l}\text { Non- } \\
\text { Drinking }\end{array}$ \\
GWQI & & & & & \\
\hline & $50>$ & $50-100$ & $100-200$ & $200-300$ & $300<$ \\
\hline
\end{tabular}

Table 6 The change in land-use area over the three time periods (Hectare)

\begin{tabular}{llllll}
\hline $\begin{array}{l}\text { Use } \\
\text { Year }\end{array}$ & Lake & Canebrake & $\begin{array}{l}\text { Human-made } \\
\text { constructions }\end{array}$ & $\begin{array}{l}\text { Agricul- } \\
\text { tural lands }\end{array}$ & Forest \\
\hline 1992 & 8.76 & 9.87 & 2.78 & 68.18 & 70.59 \\
2003 & 8.41 & 11.01 & 6.37 & 71.88 & 62.51 \\
2018 & 8.72 & 10.68 & 8.32 & 82.25 & 50.21 \\
\hline
\end{tabular}

The error being the minimum is also the evaluation criteria for the best-fit interpolation model (Dashtpagerdi et al, 2013). Cross-validation is based on leaving out one data point and determining how well we can estimate this point from the other data.
The accuracy of interpolation methods is directly dependent on the number of samples and their spatial distribution, and this issue should be considered in each study. So, three methods of IDW, Ordinary Kriging, and RBF were used to analyze groundwater quality (Table 2) spatially. These methods are the GIS-based interpolation techniques for estimating the spatial distribution compared to the other two methods, and Kriging has the slightest error because it is a linear method showing the spatial distribution of the parameter's concentration (Bucene and Zimback 2003; Hu et al, 2005; Osati et al, 2012,) so that this method were used concerning most parameters.

\section{Wilcox and Schoeller diagrams}

Several methods have been proposed for water quality assessment in agriculture, mostly based on the total soluble salts and the ionic compositions of water (Lokhande and Mujawar, 2016). Methods of representing the chemistry of water like Wilcox and Schoeller's diagrams used in this study show the proportion of ionic concentration in individual samples.
Fig. 3 Land-use types of the study area
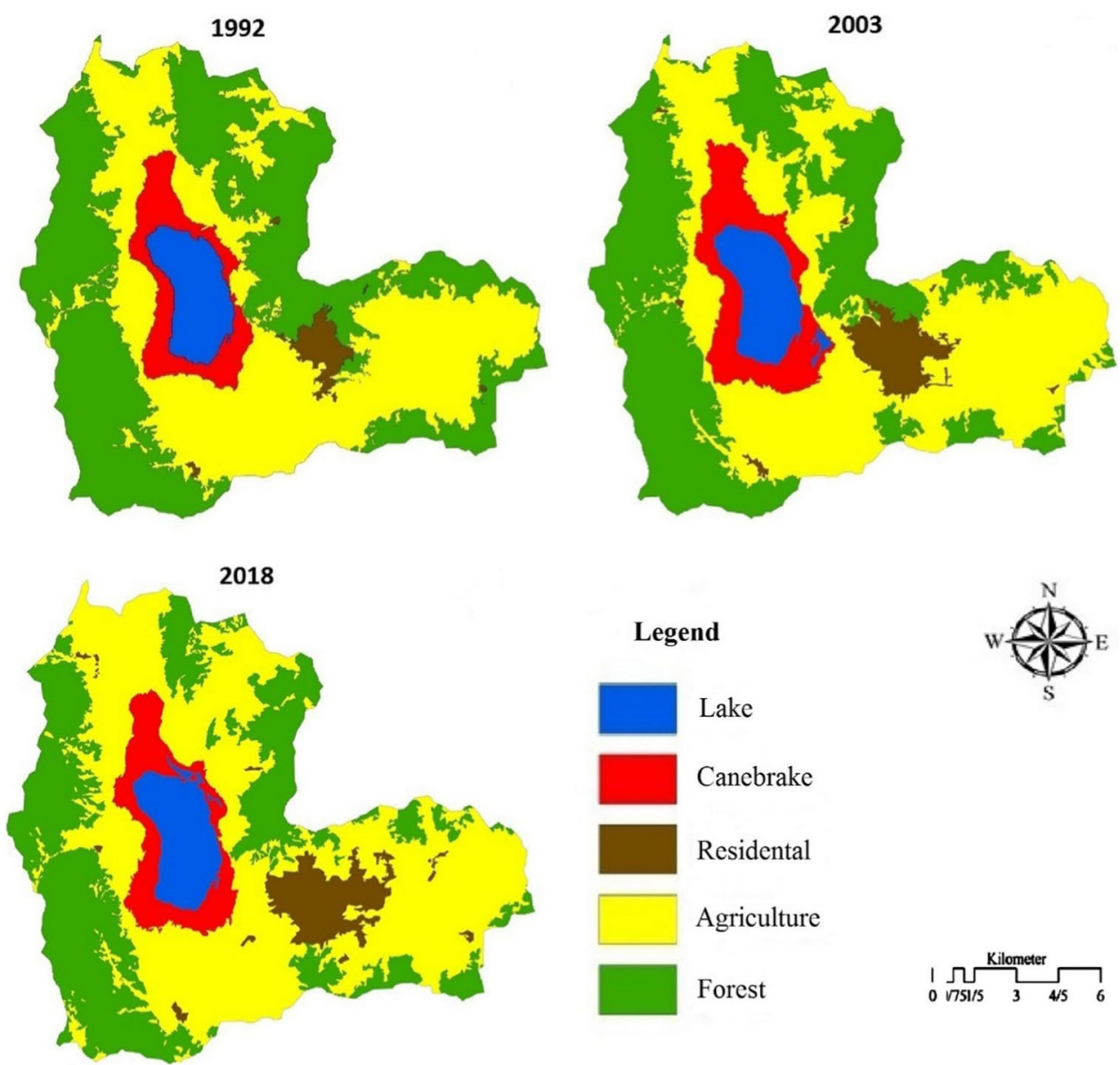
Fig. 4 The areas which changed in terms of use
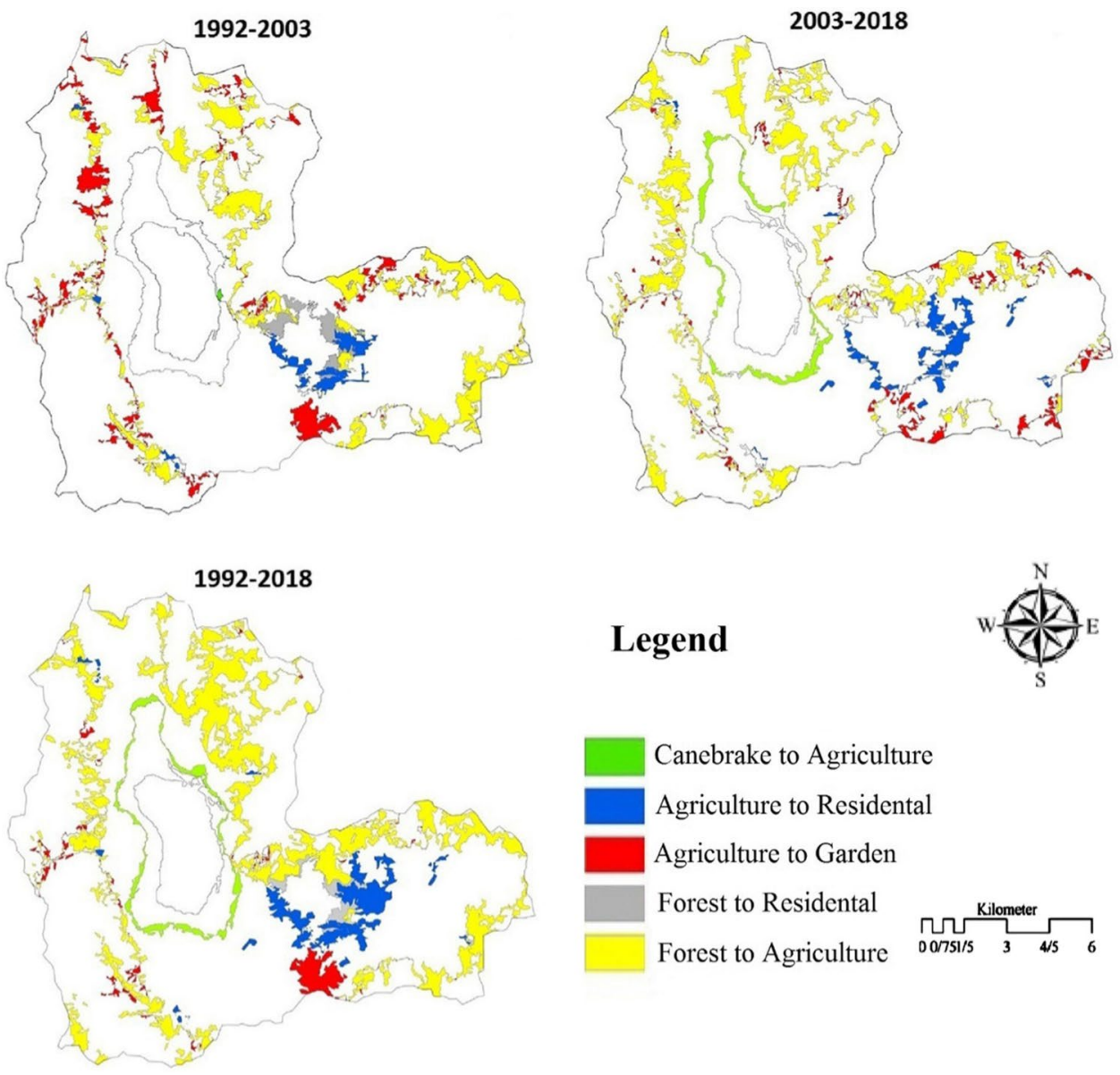

Legend

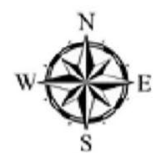

Canebrake to Agriculture

Agriculture to Residental

Agriculture to Garden

Forest to Residental

Forest to Agriculture

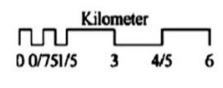

In the Wilcox diagram, two parameters of salinity (EC) and alkalinity (SAR) were analyzed by the Aq. Qa software. AqQa is software for water analyses: unit conversion, ion balance, sample mixing, basic fluid properties calculations, water chemistry diagrams (Piper, Stiff), and more. A spreadsheet that knows how to convert units, check your analyses for internal consistency, graph your data in the ways you want it graphed. The classification of the irrigation water can be determined through graphically plotting these parameters' values. In this way, water quality is divided into $\mathrm{C} 1$, C2, C3 and C4 types based on salinity hazard and S1, S2, $\mathrm{S} 3, \mathrm{~S} 4$ types based on sodium hazard. The significance and interpretations of quality ratings are summarized as follows: very good (C1S1), good (C1S2, C2S2 and C2S1), medium, or acceptable (C3S3, C3S2, C3S1, C2S3, and C1S3), and bad (C4 or S4).

Schoeller diagram is a semi-logarithmic plot representing the concentration of major ions in milliequivalent per liter and demonstrates different hydrochemical water types on the same property. It is based on five chemical parameters of sodium, chloride, sulfate, total dissolved solids (TDS), and hardness. Water is categorized into six classes: good, acceptable, medium, poor, very poor, and non-drinking by this method (Table 3).

\section{GWQI index}

The water quality index (WQI) is used to assess surface and groundwater quality for human consumption (Khangembam and Kshetrimayum, 2019). Groundwater Quality Index (GWQI) is a rating technique to prepare the combined effect of individual parameters on the overall groundwater quality calculating based on human water consumption viewpoints. In this method, the weights of different quality parameters are assumed to be inversely proportional to the corresponding parameters (Wu et al, 2017). A weight factor is then determined for each of the ten parameters, including $\mathrm{K}^{+}$, $\mathrm{Na}^{+}, \mathrm{Ca}^{2+}, \mathrm{Mg}^{2+}, \mathrm{SO}_{4}{ }^{2-}, \mathrm{HCO}^{3-}, \mathrm{Cl}^{-}, \mathrm{NO}_{3}{ }^{-}, \mathrm{TDS}$, and $\mathrm{pH}$ based on their effect on health. This index integrates the groundwater quality parameters and compares them to the international standards such as the World Health Organization (WHO) and IS 10500. In this way, a numerical weight (between 1 and 5) is driven for each parameter regarding their priority in affecting groundwater quality. Then, 
Fig. 5 Spatial variations of EC $(\mu$ Siemens.cm) in 1992-20032018
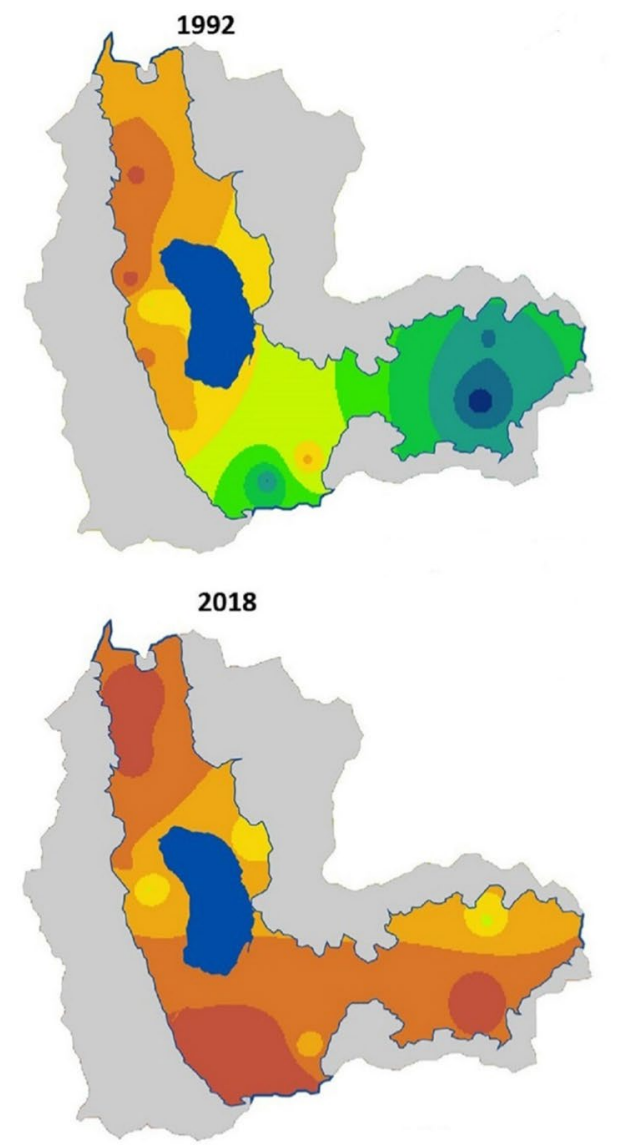

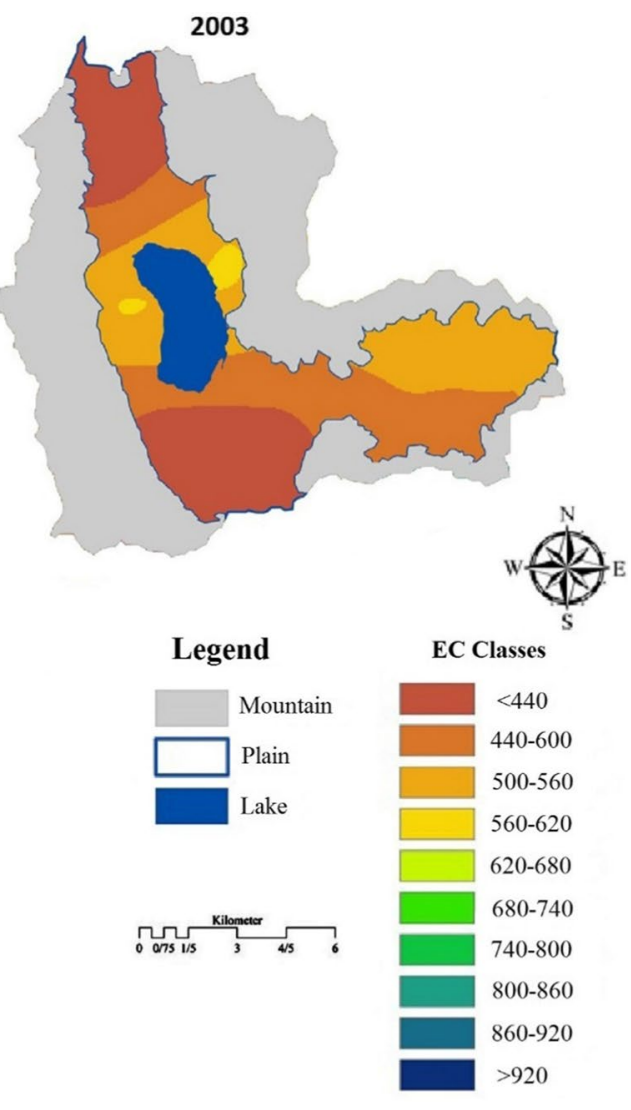

according to Eq. (1), the relative weight $\left(w_{i}\right)$ is calculated for each parameter.

$w_{r i}=w i / \sum_{i=1}^{n} w i$

where (wi) and (Wri) are, respectively, the weight and relative weight of each chemical parameter.

By dividing the concentration of each parameter $\left(c_{i}\right)$ on the concentration of the proposed measure $\left(c_{s i}\right)$ in Table 2 and Eq. (2), qualitative rank for each of them $\left(q_{i}\right)$ is calculated.

The quality rating of each parameter is calculated using Eq. (2), in which the concentration of each chemical parameter (Ci) is divided by their WHO standard values ( $\mathrm{Si}$ ).

$(q i)=\frac{c_{c}}{s_{i}} \times 100$

Finally, the GWQI index is calculated according to Eq. 3. The results of this method are shown in Table 4.

$G W Q I=\sum_{i=1}^{n}\left(w_{r i} \times q_{i}\right)$
In general, the quality of underground water resources can be classified into five categories of excellent, good, bad, very bad, and non-drinking (Table 5).

\section{Results}

\section{Land-use change}

The total area of the basin is $160.18 \mathrm{~km} 2$. Land-use types were classified into five categories including, human-made constructions (towns, villages, industrial facilities, mines, etc.), lake, canebrake, forest, and agricultural lands. Inside this region, there is no rangeland except a few tiny patches used by farmers to feed livestock, so they were considered as agricultural lands. Table 6 shows the change in land-use area over the three time periods. Forest area in 1992, 2003 and 2018 was 70.6, 62.5 and 50.2 hectares, respectively, which shows a significant reduction, $22 \%$, during this study period. On the other hand, the area of farmlands and human-made constructions has increased by $20 \%$ and $200 \%$, respectively. As it is shown in Fig. 3, the dominant use covered a considerable part of this area is oak forest. Although the forest was the most extensive land use in 1990, the development of 
Fig. 6 Spatial variations of SAR in 1992-2003-2018

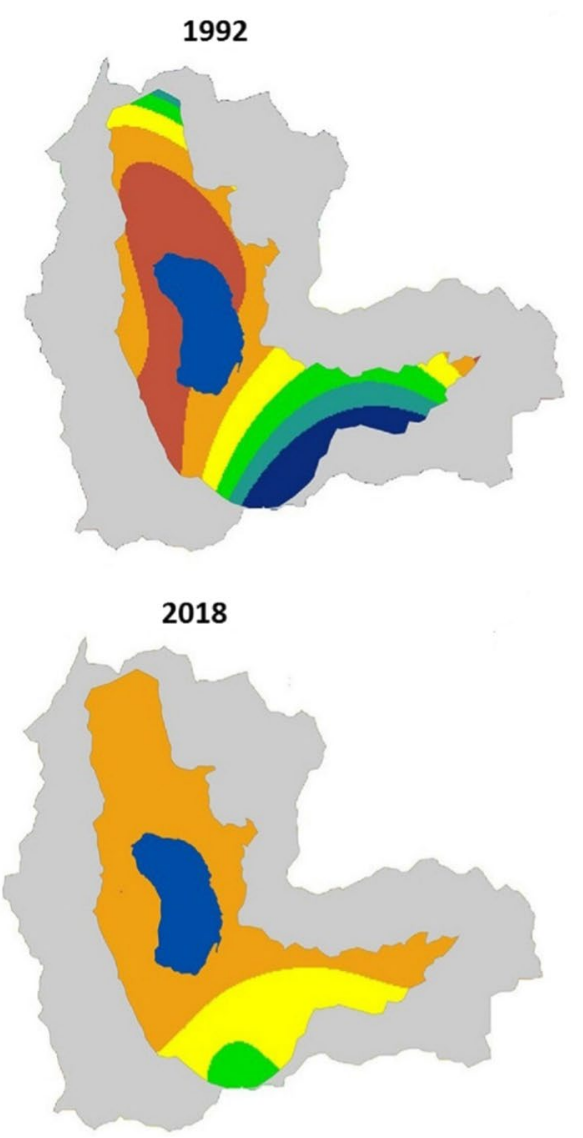

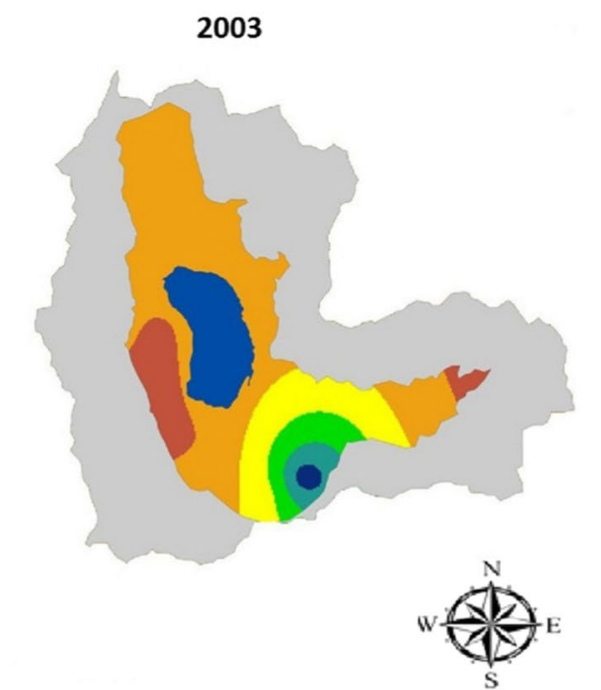

Legend

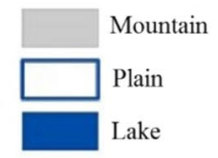

SAR Classes

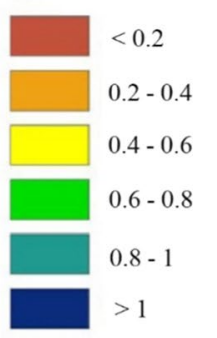

agriculture and the city area has reduced this natural cover during the given period. These changes mainly occurred in the east of the basin in 2003, while the central part of forest lands in the west of the basin was allocated to agriculture in 2018. As a result, a significant area of forests has been replaced by agricultural use, the dominant cover in 2018, while the area of forest has declined sharply (Fig. 4).

\section{Groundwater quality}

\section{Interpolation}

The results of interpolation of groundwater quality parameters (EC, SAR, $\mathrm{SO}_{4}{ }^{2-}$ and $\mathrm{HCO}^{3-}$ ) based on choosing the best-fit interpolation model are shown in Figs. 5, 6, 7, 8. Therefore, three methods of IDW, Ordinary Kriging, and RBF were used to analyze groundwater quality based on the least root-mean-square error (RMSE).

It is clear from Fig. 5 that the amount of EC (Electrical Conductivity) on the north and southeast of the study area was lower and higher, respectively. In 1992, EC was higher on the southeast side of the area (more than 680) than the areas around the lake, at about 500. This parameter's Figs decreased almost for the entire region, significantly on the east side of the basin in 2003. This trend remained the same in 2018 which due to the change of land use and also the decrease in rainfall, the study of a single parameter (EC) does not show the correct trend of total groundwater quality, which may be due to the drop in groundwater level and the passage of geological layers.

As illustrated in Fig. 6, the spatial variation of SAR amount (Sodium Adsorption Ratio) was remarkable during the given period. In 1992, SAR was less than 0.2 in the area around the lake while Fig. 6 for the north and the south of the study area were higher, more than 0.6. In 2003 and 2018, this indicator increased around the lake to $0.2-0.4$ and decreased on the north and south of the basin to $0.2-0.4$ and less than 0.8 , respectively.

The concentration of sulfate anion $\left(\mathrm{SO}_{4}{ }^{2-}\right)$ fluctuated widely from 1992 to 2018 (Fig. 7). This parameter's concentration varied in spatial distribution ranging from less than 0.1 to $0.6 \mathrm{mEq} / \mathrm{L}$ while the entire area had the same concentration (less than 0.1) in 2003. In 2018, Fig. for SO4 rose and was $0.3-0.4$ in the central part of the basin, including around the lake.

The concentration of $\mathrm{HCO}^{3-}$ fluctuated between 1992 and 2018 (Fig. 8). In 1992, this parameter was 300-330 mEq/L, while Fig. varied from less than 0.2 in the north and south of the basin to more than 360 on the east side of the basin and around the lake. The amount of $\mathrm{HCO}^{3-}$ significantly 
Fig. 7 Spatial variations of $\mathrm{SO}_{4}{ }^{2-}$ (meq.1) in 1992-20032018
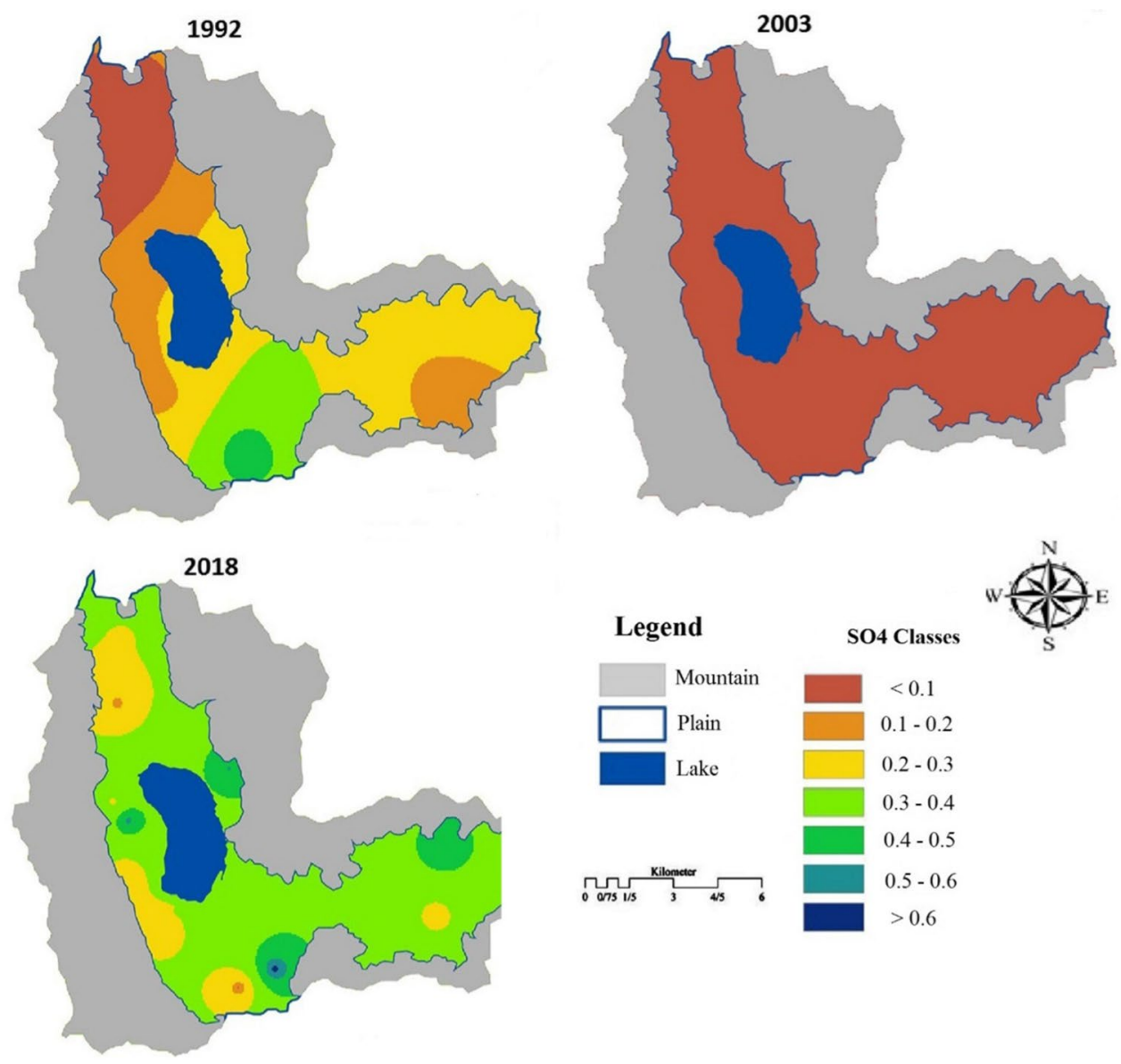

decreased in 2018, especially around the lake in which the concentration fell, at $270-300 \mathrm{mEq} / \mathrm{L}$.

\section{Schoeller and Wilcox diagrams}

The chemical parameters of the area's groundwater were compared with the standard guideline of values published by the World Health Organization (WHO) standards for irrigational suitability. In this way, hydrochemical data was plotted in standard graphs Schoeller and Wilcox's diagrams (Figs. 9 and 10). According to the Schoeller diagram, the groundwater quality during the given period was suitable for drinking. As presented in the Wilcox diagram, most wells' groundwater quality is good (C2.S1) in the three years. And it is categorized in a very good class (C1.S1) for Ney well in 2018.

Results of the groundwater changes regarding drinking consumption (Schoeller diagram) and agriculture (Wilcox diagram) show that changes in the qualitative class of water were low. The groundwater is suitable for irrigation.

\section{GWQI index}

GWQI index was calculated based on the chemical analysis of 11 wells in 1992, 2003, and 2018 to evaluate the change of groundwater quality for drinking (Fig. 11). The GWQI index results for all stations show that the index has increased, which means that the groundwater quality has decreased in almost all stations in 2003, which was a dry year. In 2018, this index showed a significant decrease compared to other stations in Stations (Serah $\mathrm{Ne}$ ), which is the downstream of residential areas. After a severe and long drought in 2003, the GWQI index shows that the quality of water in Serah Nei point (like most wells in this region) has been high. However, in this station, changes were regular. In 2018, when rainfall was close to the standard conditions, water quality increased compared to 2003; however, it was worse than in 1992. It can be attributed to this well's location at Marivan downstream that is affected by significant changes in land degradation and the development of residential lands. Contrary to other stations, the GWQI index for Nei and Lenj Abaad has been reversed and has decreased, which can be due to local causes. 
Fig. 8 Spatial variations of $\mathrm{HCO}^{3-}$ (meq.1) in 1992-20032018
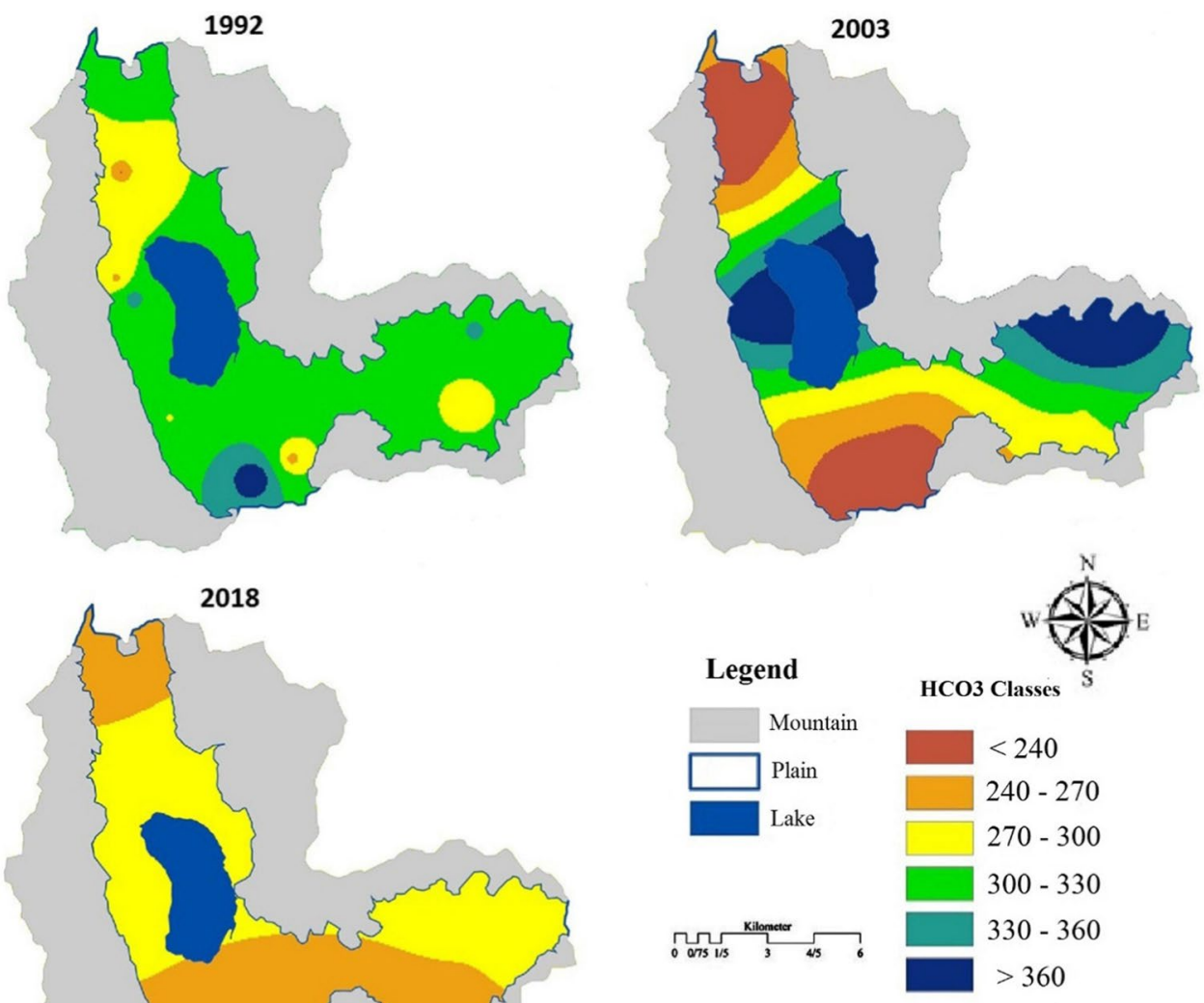

\section{Discussion}

Spatial analysis of the groundwater quality parameters of Zrebar lake watershed basin (Kurdistan province/Iran) from 1992 to 2018 shows heterogeneous trends. The trend of change in some groundwater quality factors has been fluctuating, and some of them have a direct tendency, complicating the interpretation of the causes of groundwater quality change in the area. However, comparing the results of groundwater quality changes with drinking consumption (Schoeller diagram) and agriculture (Wilcox diagram) standards revealed that water quality changes have been low, and groundwater of the area was classified in well and medium categories. Additionally, in 2018, the quality of water has upgraded to a good grade and to top-level in Nei well, due to the local causes.

Therefore, GWQI index was used in order to better analyze the trend of qualitative changes in terms of drinking.
The values of this index show that changes in this index have been occurred along with climatic change and landuse change meaning that in 2003, after a significant and severe period of drought, the quality of water has deteriorated. Since there are a number of parameters affecting water quality, in some cases, the qualitative changes are difficult to interpret. After a severe and long drought in 2003, GWQI index shows that the quality of water in Serah Nei point (like most of the wells in this region) has been high. However, in this station, changes were regular. In 2018, when rainfall was close to the normal conditions, water quality increased compared to 2003; however, it was worse compared to 1992. It can be attributed to the location of this well at Marivan downstream that is affected by significant changes in land degradation and the development of residential lands. Contrary to other stations, GWQI index for Nei and Lenj Abaad has been reversed trend and has decreased which can be due to the local causes.

The greatest change in the quality of groundwater resources was in areas where the area of agricultural land 

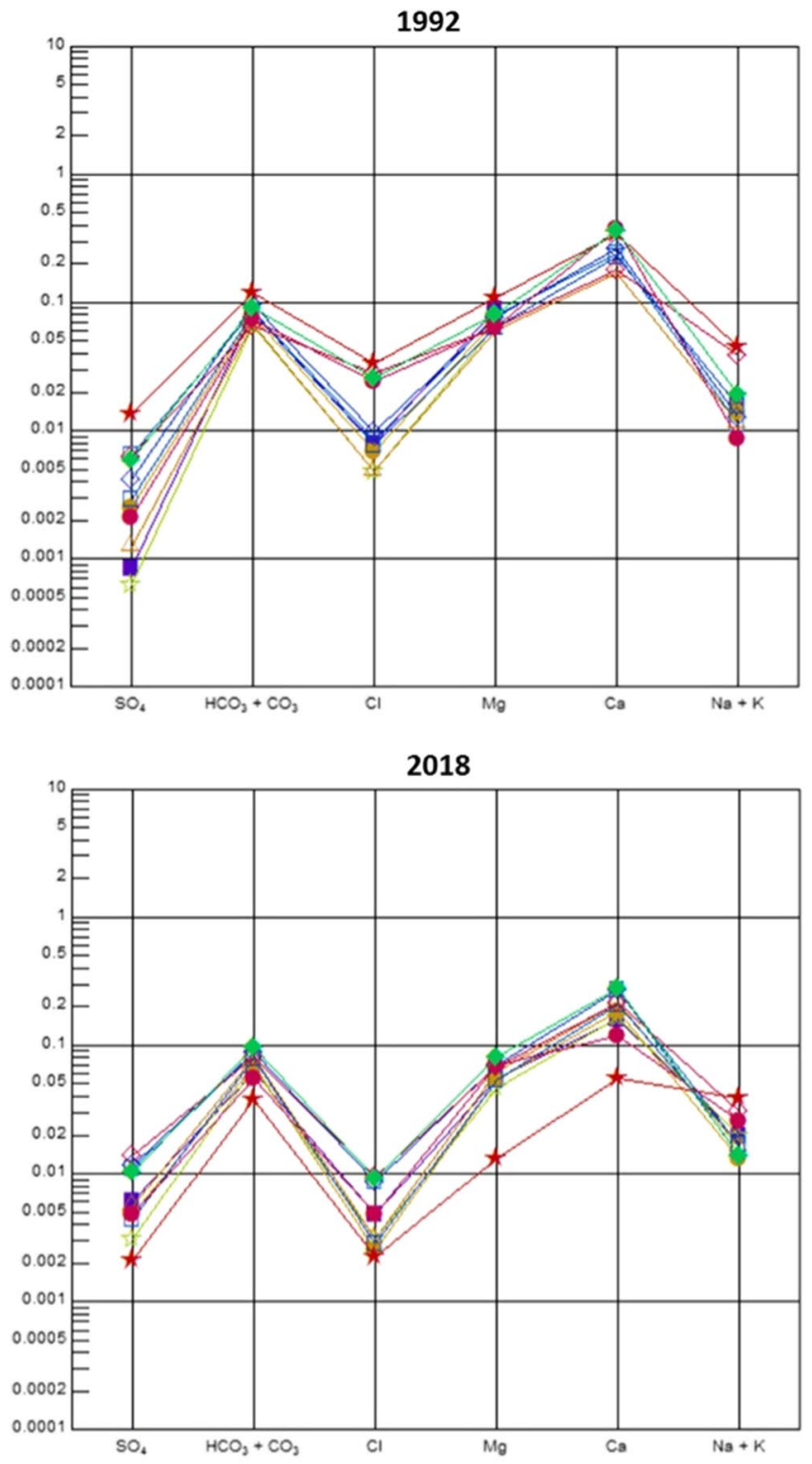

Fig. 9 Schoeller diagram in 1992-2003-2018

and residential areas significantly. For example, the concentration of SO4 and SAR has risen around the lake, where the forest was destroyed for agricultural purposes. However, a significant relationship cannot be recognized between landuse change and the trend of $\mathrm{EC}$ and $\mathrm{HCO}^{3-}$ because $\mathrm{EC}$ has reduced between 1992 and 2018 in the areas with the most change of land use, and the concentration of $\mathrm{HCO}^{3-}$ has fluctuated in these areas. This is because the rate of fertilizer use increases as a result of agricultural land development, resulting in increased concentrations of nitrate and phosphate contaminants in water resources.

The results obtained from detecting the trend of landuse change in this study was similar to other studies

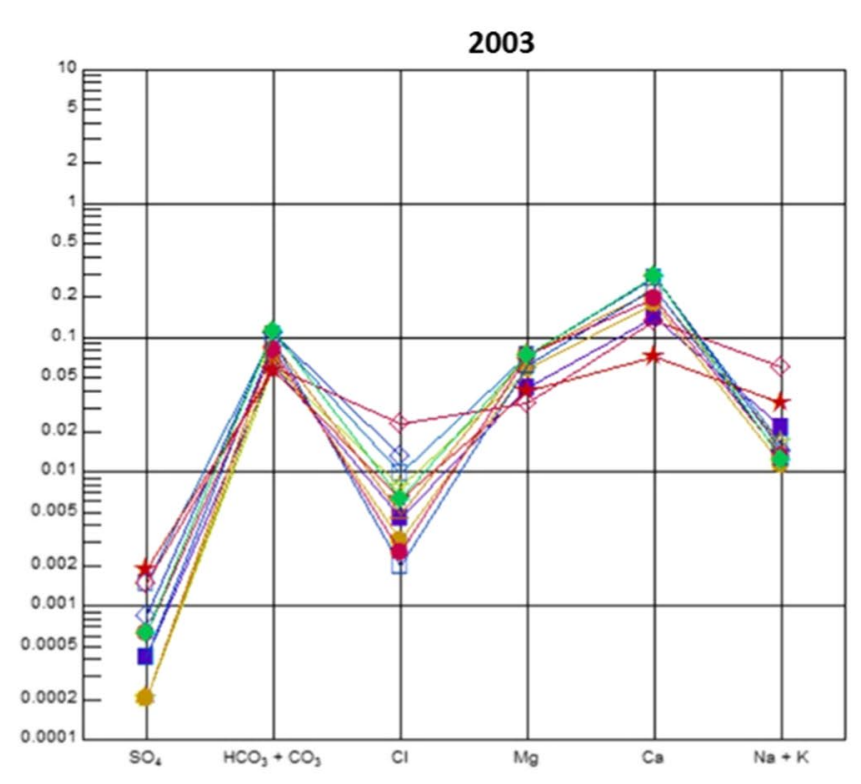

\section{Legend}

Water well stations

- Kollan

- Barda Rasha

\& Yengijeh

$\triangle$ Pirsafa

- Kani Sanan

$\diamond$ Dare Tfe 1

- Dare Tfe 2

$\star \mathrm{Ne}$

$\diamond$ Seray $\mathrm{Ne}$

- Lanjawa

- Tazawa

conducted in other parts of Iran and the world (Geist and Lambin, 2001, Holmgren, 2006., Václavík and Rogan 2009, Hosonuma et al. 2012., Hansen et al. 2013., d'Annunzio et al. 2015). For example, about $32 \%$ of the world's tropical forests were destroyed between 2000 and 2012 (Hansen et al. 2013). Direct causes of deforestation include agricultural expansion, timber extraction (for example, logging or harvesting for fuel or charcoal), and the development of infrastructure such as road construction and urban development, of which agricultural land development is the most important. In order to develop agricultural lands to meet food needs, large areas of forests in Africa, Asia, and South America have been destroyed. 


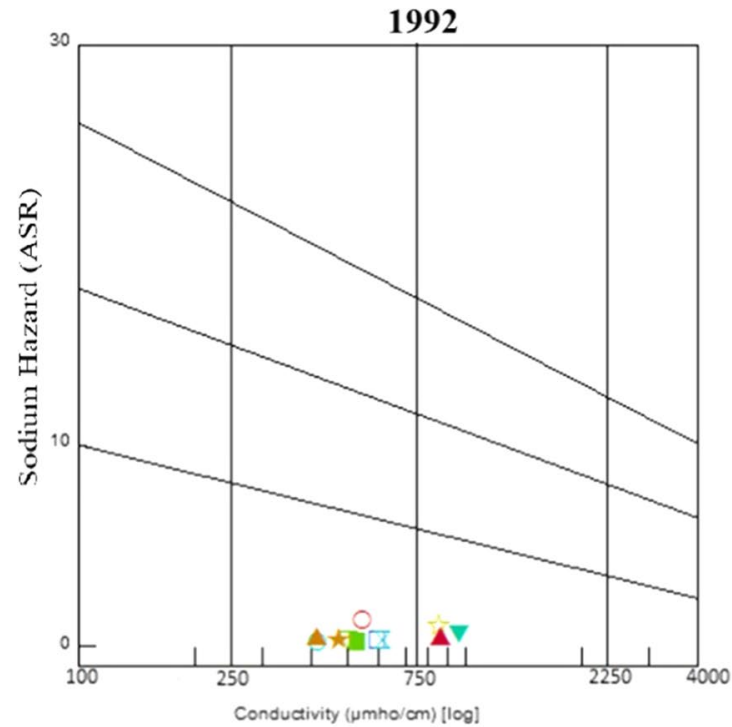

2018

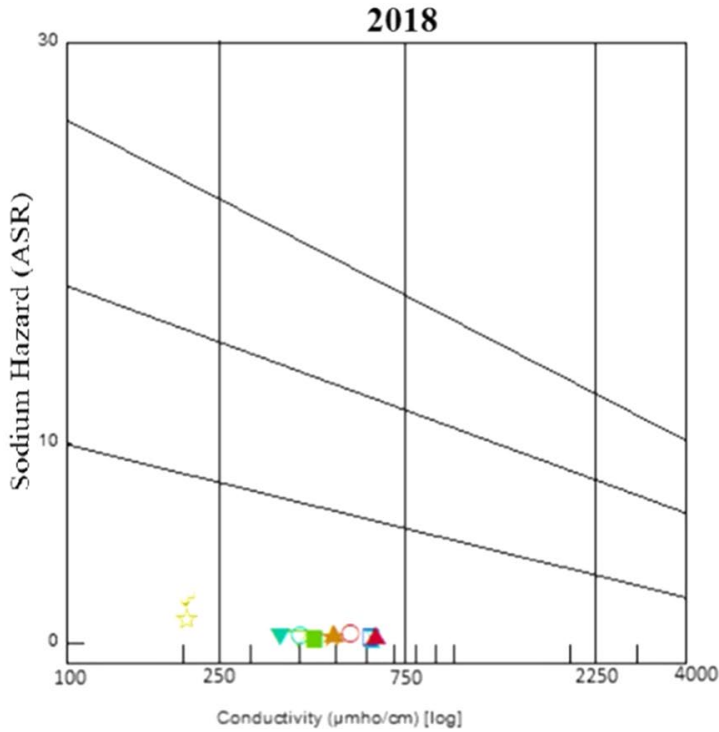

Fig. 10 Wilcox diagram in 1992-2003-2018

More than $70 \%$ of the trees cut down in these areas was in order to convert forest into agricultural land (Nepstad et al. 2008; Guitierrez-Velez et al. 2011; d'Annunzio et al. 2015). Similarly, various parts of Iran's forests have been destroyed over the past decades and have become farmland (Mohammadi and Shataee, 2010, Jorabian et al. 2014, Rajaei et al, 2021). For example, in a study conducted for Tajan watershed, located in north of Iran, about $1.6 \%$ of the forest have decreased during 1986-2010 (Rajaei et al, 2021).

Evaluating of the Zrebars Lake water quality by WQI (Sharifinai et al. 2013) revealed the similar results to this study. It showed that the lake is slightly polluted and could be placed in average quality class. However, most studies conducted for the case study area have mainly focused on

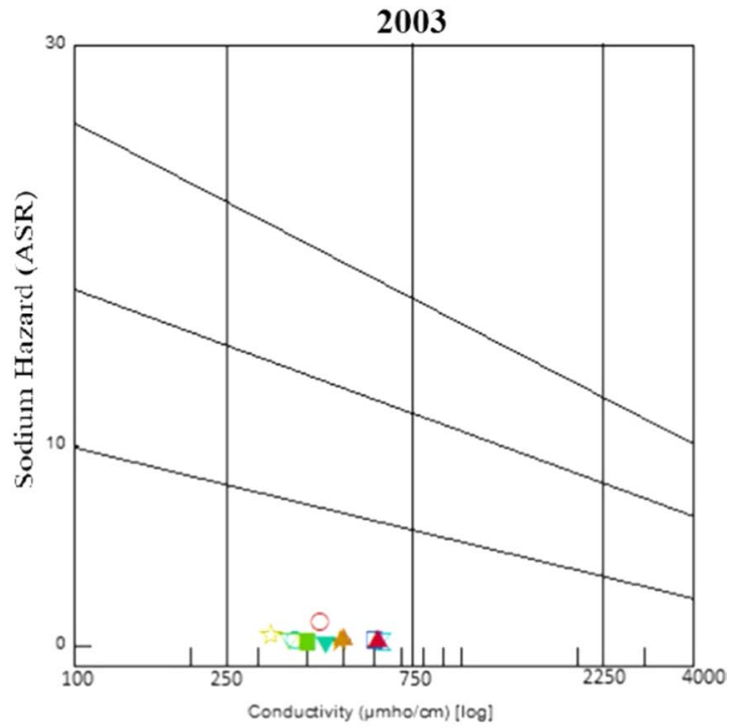

Legend

Water well stations

- Kollan

- Barda Rasha

Yengijeh

- Pirsafa

- Kani Sanan

$\diamond$ Dare Tfe 1

- Dare Tfe 2

$\star \mathrm{Ne}$

$\checkmark$ Seray Ne

- Lanjawa

- Tazawa

quality parameters such as nitrate and phosphate and their results show that agricultural development is one of the main reasons for increasing the concentration of these two parameters. Since the main cause of nitrate and phosphate emissions in agricultural fertilizers, the proposed solutions to improve water quality were mainly focused on agriculture, such as changing the type of cultivation, the amount of fertilizer used and farming management. None of these studies considered upstream-downstream relationships, including deforestation and increased agricultural activity. 


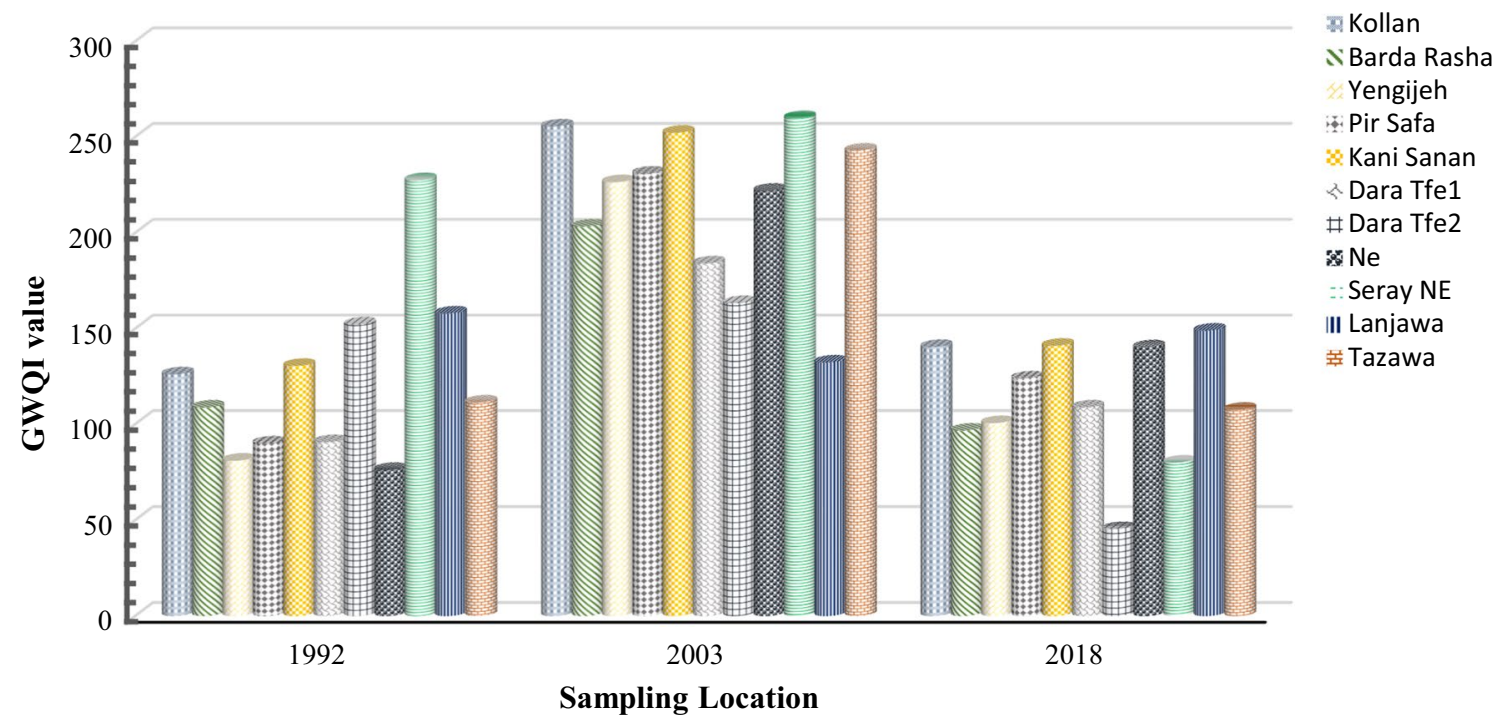

Fig. 11 The chart GWQI index in 1992-2003-2018

\section{Conclusion}

This paper presented land-use change, groundwater quality change and the best way to study these changes as well as the relationship between land use and groundwater quality. This study revealed that GWQI index is the most appropriate method to measure and assess the trend of groundwater quality in the area because all quality parameters were rated based on their value and importance, and groundwater quality changes were matched to land-use changes and drought. According to the complexity and the number of the parameters affecting the groundwater quality including human factors and climatic fluctuations, determining the role of land-use changes on groundwater quality is significant challenges for researchers. In addition, in order to more accurately study the impact of land-use change on groundwater quality, it is necessary to measure other quality parameters, especially nitrate and phosphate because the development of agriculture and subsequent use of chemical fertilizers increases the emission of these pollutants. Since Zrebar Lake fed by groundwater resources and no river comes in this lagoon, pollution of groundwater resources leads to pollution of this ecosystem and affects the life of animal and plant species. Therefore, it is suggested that other quality parameters of groundwater resources are studied in the future and not only their past trends but also their changes in the future be modeled. Different scenarios could be developed for the future with focus on conservation principles and land use and groundwater quality changes could be modeled to help pollution mitigation efforts.
Acknowledgements The authors thank the laboratory of Department of Arid and Mountainous Reclamation Region, Faculty of Natural Resources, University of Tehran for their excellent technical assistance.

Funding This research did not receive any specific grant from funding agencies in the public, commercial, or not-for-profit sectors.

\section{Declarations}

Conflict of interest The authors declared that they have no conflict of interest.

Open Access This article is licensed under a Creative Commons Attribution 4.0 International License, which permits use, sharing, adaptation, distribution and reproduction in any medium or format, as long as you give appropriate credit to the original author(s) and the source, provide a link to the Creative Commons licence, and indicate if changes were made. The images or other third party material in this article are included in the article's Creative Commons licence, unless indicated otherwise in a credit line to the material. If material is not included in the article's Creative Commons licence and your intended use is not permitted by statutory regulation or exceeds the permitted use, you will need to obtain permission directly from the copyright holder. To view a copy of this licence, visit http://creativecommons.org/licenses/by/4.0/.

\section{References}

Adham AKM, Kobayashi A, Murakami A (2011) Effect of climatic change on groundwater quality around the subsurface dam. Int $\mathbf{J}$ of Geomate 1:25-31

Bounoua L, Nigro J, Zhang P, Thome K, Lachir A (2018) Mapping urbanization in the United States from 2001 to 2011, 2018. Appl Geogr 90:123-133

Bucene LC, Zimback CRL (2003) Comparison of methods of interpolation and spatial analysis of $\mathrm{pH}$ data in Botucatu. SP IRRIGA $8: 21-28$

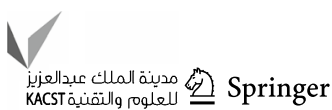


d'Annunzio R, Sandker M, Finegold Y, Min Z (2015) Projecting global forest area towards 2030. For Ecol Manage 352:124-133

Dashtpagerdi MM, Nohegar A, Vagharfard H, Honarbakhsh A, Mahmoodinejad V, Noroozi A, Ghonchehpoor D (2013) Application of spatial analysis techniques to select the most suitable areas for flood spreading. Water Resour Manage 27:3071-3084

Du CH, Cai F, Zidan MA, Ma W, Lee SH, Lu W (2017) Reservoir computing using dynamic memristors for temporal information processing. Nature Commun 8:52-59

Elci A, Polat R (2010) Assessment of the statistical significance of seasonal groundwater quality change in karstic aquifer system near Izmir- Turkey. Environ Monit Assess 172:445-462

Geist HJ, Lambin EF (2001) What drives tropical deforestation. LUCC Rep Ser 4:116

Gutierrez VH, DeFries R, Pinedo-Vasquez M, Uriarte M, Padoch C, Baethgen W, Fernandes K, Lim Y (2011) High-yield oil palm expansion spares land at the expense of forests in the Peruvian Amazon. Environmental Research Letters 6:044029

Hansen MC, Potapov PV, Moore R, Hancher M, Turubanova SA, Tyukavina A, Thau D, Stehman SV, Goetz SJ, Loveland TR et al (2013) High-resolution global maps of 21st-century forest cover change. Science 342:850-853

Hasan, S.S., et al. (2020) Impact of land use change on ecosystem services: A review. Environmental Development, 34: p. 100527

He S, Li P, Wu J, Elumalai V, Adimalla N (2020) Groundwater quality under land use/land cover changes: a temporal study from 2005 to 2015 in Xi' an, northwest China. Hum Ecol Risk Assess Int J 26(10):2771-2797

Henri CV, Harter T, Diamantopoulos E (2021) Stochastic assessment of the effect of land-use change on nonpoint source-driven groundwater quality using an efficient scaling approach. Stoch Env Res Risk Assess 35(5):959-970

Holmgren, P (2006) Global land use area change matrix. In Input to the Fourth Global Enviromental Outlook (GEO-4)

Hosonuma N, Herold M, De Sy V, De Fries RS, Brockhaus M, Verchot L, Angelsen A, Romijn E (2012) An assessment of deforestation and forest degradation drivers in developing countries. Environ Res Lett 7:44009

Houben G, Tunnermeier T, Eqrar N, Himmelsbach T (2009) Hydrogeology of the Kabul Basin (Afghanistan) Part II: Groundwater Geochemistry. Hydrogel J 17:935-948

Hu K, Huang Y, Li H, Li B, Chen D, White R (2005) Spatial variability of shallow groundwater level, electrical conductivity, and nitrate concentration, and risk assessment of nitrate contamination in the North China Plain. Env Int J 31:896-903

Hyandye C, Martz LW (2017) A Markovian and cellular automata land use change predictive model of the Usangu Catchment. Int J Remote Sens 38:64-81

Imani S, Delavar M, Niksokhan M (2016) "Identification of critical source areas of nutrient loads using SWAT model: Case study, Zrebar Lake Watershed, Iran"

Imani S, Delavar M, Niksokhan M (2016) "Periodical effects of land uses on water quality of Zrebar Lake."

Karimi H, Jafarnezhad J, Khaledi J, Ahmadi P (2018) Monitoring and prediction of land use/land cover changes using CA-Markov model: a case study of Ravansar County in Iran. Arab J Geosci 11(19):1-9

Ketata M, Hamzaoui F, Gueddari M, Bouhila R, Riberio L (2011) Hydrochemical and statistical study of groundwater in gabessouth deep aquifer (South-eastern Tunisia). Phys Chem Earth $36: 187-196$

Khangembam S, Kshetrimayum KS (2019) Evaluation of hydrogeochemical controlling factors and water quality index of water resources of the Barak valley of Assam. Northeast India Groundwater Sust Develp 8:541-553
Kourosh Niya A, Huang J, Karimi H, Keshtkar H, Naimi B (2019) Use of intensity analysis to characterize land use/cover change in the biggest island of Persian Gulf, Qeshm Island, Iran. Sustainability 11(16):4396

Labat D, Goddéris Y, Probst JL, Guyot JL (2004) Evidence for global runoff increase related to climate warming. Adv Water Resour 27:631-642

Li P, Tian R, Liu R (2019) Solute geochemistry and multivariate analysis of water quality in the guohua phosphorite mine, Guizhou Province. China Expo Health 11(2):81-94. https:// doi.org/10.1007/s12403-018-0277-y

Lokhande PBH, Mujawar HA (2016) Graphic interpretation and assessment of water quality in the Savitri River Basin. Int J Sci Eng Res 7:1113-1123

Malakutian M, Karami A (2004) Chemical quality variability in groundwater of Bam plain from 1998-2004. Clinical Journal of Hormozgan 2:101-109

Mohammadi J, Shataee Joibary S, Yaghmaee F, Mahiny AS (2010) Modelling forest stand volume and tree density using Landsat ETM+ data. Int J Remote Sens 31:2959-2975

Mohammadi M, Ghalahani MM, Ebrahimi K (2011) Spatial variability of nitrate in groundwater in Qazwin plain, the journal of water research, 8, 41-52

Nepstad DC, Stickler CM, Filho BS, Merry F (2008) Interactions among Amazon land use, forests and climate: prospects for a near-term forest tipping point. Philos. Trans. R. Soc. B Biol. Sci., 363, 1737-1746.

Nistor M-M (2019) Climate change effect on groundwater resources in South East Europe during 21st century. Quatern Int 504:171-180

Nistor M-M, Mîndrescu M (2019) Climate change effect on groundwater resources in Emilia-Romagna region: An improved assessment through NISTOR-CEGW method. Quatern Int 504:214-228

Niya AK, Huang J, Kazemzadeh-Zow A, Karimi H, Keshtkar H, Naimi B (2020) Comparison of three hybrid models to simulate land use changes: a case study in Qeshm Island, Iran. Environ Monit Assess 192(5):1-19

Osati KH, Salajegheh A, Arkhi S (2012) Spatial variability of nitrate in groundwater using geostatistics (Case study; Kordan plain), J Pasture Watershed Manag. 5, 461-472

Peña-Haro S, Llopis-Albert C, Pulido-Velazquez M, Pulido- Velazquez D (2010) Fertilizer standards for controlling groundwater nitrate pollution from agriculture: El Salobral-Los Llanos case study, Spain. J Hydrology 392:174-187

Prasad R, Mondal N, Banerjee P, Nandakumar M, Singh V (2008) Deciphering potential groundwater zone in hard rock through the application of GIS. Environ Geol 55(3):467-475

Rajaei F, Dahmardeh Behrooz R, Ahmadisharaf E, Galalizadeh S, Dudic B, Spalevic V, Novicevic R (2021) Application of Integrated Watershed Management Measures to Minimize the Land Use Change Impacts. Water 13(15):2039

Ramsar Convention (2019) https://www.ramsar.org/news/islamicrepublic-of-iran-designates-zarivar-as-a-ramsar-site

Riedel T, Kübeck C (2018) Uranium in groundwater-a synopsis based on a large hydrogeochemical data set. Wat Res 129:29-38

Sadeghi A, Khaledi J, Nyman P (2018) Rainfall variability and landuse change in arid basins with traditional agricultural practices; insight from ground water monitoring in Northwestern Iran. J Earth Sci Clim Change 9(498):2. https://doi.org/10.4172/21577617.1000498

Sharifinia M, Ramezanpour Z, Imanpour J, Mahmoudifard A, Rahmani T (2013) Water quality assessment of the Zarivar Lake using physico-chemical parameters and NSF-WQI indicator, Kurdistan Province-Iran. Int J Adv Biol Biomed Res 1(3):302-312 
Siebert S, Burke J, Faures JM, Frenken K, Hoogeveen J, Döll P, Portmann FT (2010) Groundwater use for irrigation - a global inventory. Hydrol Earth Syst Sci 14:1863-1880

Singh S, Singh C, Mukherjee S (2010) Impact of land-use and landcover change on groundwater quality in the Lower Shiwalik hills: a remote sensing and GIS based approach. Open Geosci 2(2):124-131

Solomon S, Plattner GK, Knutti R, Friedlingstein P (2009) Irreversible climate change due to carbon dioxide emissions. Proc Natl Acad Sci USA 106:1704-1709

Tayfur G, Kirer T, Baba A (2008) Groundwater quality and hydrogeochemical properties of Torbalı Region, Izmir, Turkey. Environ Monit Assess 146:157-169

Václavik T, Rogan J (2009) Identifying trends in land use/land cover changes in the context of post-socialist transformation in central Europe: a case study of the greater Olomouc region. Czech Republic Gisci Remote Sens 46:54-76

Velazquez MP, Haro SP, Garcia-Prats A, Mocholi-Almudever AF, Henriquez L (2015) Integrated assessment of the impact of climate and land use changes on groundwater quantity and quality in the Mancha Oriental system (Spain). Hydrology Earth Syst Sci 19:1677-1693
Vousoughi FD, Dinpashoh Y (2013) Trends of groundwater quality of ardabil plain using the spearman Method. J Environ Stud 38:17-28

Wu Z, Zhang D, Cai Y, Wang X, Zhang L, Chen Y (2017) Water quality assessment based on the water quality index method in Lake Poyang: The largest freshwater lake in China. Sci Rep 7:1-10

WWAP (World Water Assessment Programme). (2009) World Water Development Report 3: Water

Yidana SM, Banoeng-Yakubo B, Akabzaa TM (2010) Analysis of groundwater quality using multivariate and spatial analyses in the Keta basin Ghana. J Afr Earth Sci 58:220-234

Yousefi S, Moradi H, Hosseini S, Mirzaee S (2011). "Land use change detection using Landsat TM and ETM+ satellite images over marivan."

Publisher's Note Springer Nature remains neutral with regard to jurisdictional claims in published maps and institutional affiliations. 